\title{
Correspondence
}

\section{研究会紹介 希薄溶液の流動学研究会}

\author{
牛田 晃臣 ${ }^{*} \dagger$, 日出間 るり ${ }^{* *}$, 玉野 真司 ${ }^{* * *}$, 梶谷 忠志 ${ }^{* * * *}$, 堀本 康文**** \\ 新潟大学, , 神戸大学 ${ }^{* *}$, 名古屋工業大学 ${ }^{* * *}$, 富士フイルム株式会社 ${ }^{* * * *}$, 東京理科大学 ${ }^{* * * * *}$
}

（原稿受理：2018 年 9 月 19 日）

\section{1.はじめに}

希薄溶液の流動学研究会は 2013 年 6 月に設立されました。 発端は，同年 5 月に開催された第 40 年会に打いて，当時の 会長であった上田隆宣先生から扮声掛け頂いたことによりま す. 懇親会の場で, 上田先生が「私が会長の間に新しい研究 会を 1 つ作りたい，現在，高分子溶液の研究会がないことが 気になっている. 若い研究者の幹事を集めて, 研究会を立ち 上げてくれないか.」と扔っしゃったことを今でも鮮明に覚 えています。まだ若輩者の研究者が新しい研究会を設立でき るものなのか半信半疑でしたが, 上田先生を始めとする発起 人の先生方の後押しにより, 幹事 4 人体制で活動をスタート できました。その後 5 年が経過し，活動範囲が広がってきた ことを踏まえ，現在は幹事 5 名体制で活動しています。ここ では簡単ではありますが，これまでの研究会活動の紹介をさ せて頂きます、

\section{2. 研究会の目的}

研究会のテーマ名にもある「希薄」溶液とは, 例えば界面 活性剂や高分子を添加した水溶液で, 低濃度であっても非 ニュートン性など特異な流動現象を示す流体のことです。こ のような流動現象は, 流体輸送, 生体内流動, 食品, 印刷な どの広い分野に関係しており，解明が急がれる分野です。し かしながら，希薄溶液は既存の実験装置での測定は困難なこ とが多く, このため, 多くの研究者は独自の実験手法や測定 装置を開発し研究を行っているのが現状です。このような状 況に鑑み，希薄溶液の流動現象を対象としたユニークな実験 装置や測定手法を持つ研究室を訪問し, 開発者と意見交換す る「見学型」の研究会 (講演・見学会) を開催することで, 新たなレオロジー測定技術構築や流動現象解明に寄与するこ とを研究会の目的としています。な挹「見学型」のスタイ ルを提案されたのは，発起人の扔一人である長岡技術科学大 学の高橋勉先生であり，「幹事は若手であるし，自分たちの 興味がある研究室に声を掛けてみてはどうか.」と温かいお 言葉を頂きました，研究室を見学できる機会というのは，実 際のところなかなかないことから，「これは面白そう」と早 速，ご提案を取り入れることにしました，見学会の形式を 取ったことで参加者と開発者の間で気軽に議論ができるよう

\footnotetext{
† $\overline{9}$ 950-2181 新潟県新潟市西区五十嵐 2 の町 8050

E-mail: ushida@eng.niigata-u.ac.jp

Tel\&Fax: +81-25-262-7009

になり, 参加者の方にも大変好評で研究会の特徵にもなって いることから，今後も継続していく予定です．

\section{3. これまでの活動}

年に数回，学会関係のイベント（年会や討論会など）の前 後に合わせて講演・見学会を開催しています。これまでに開 催した講演・見学会を Table I にまとめました。キックオフ として，2013 年 9 月に第 1 回講演・見学会を山形大学で開

(a)

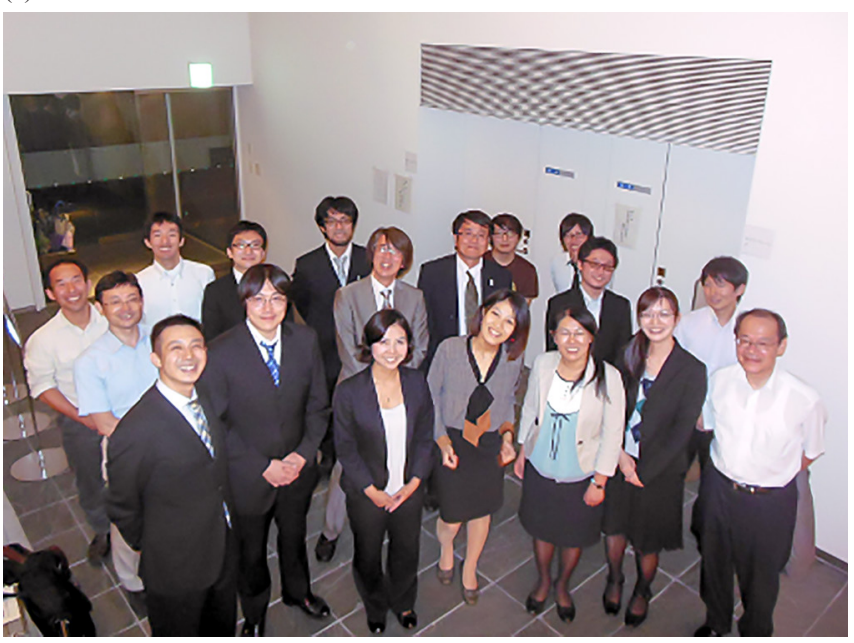

(b)

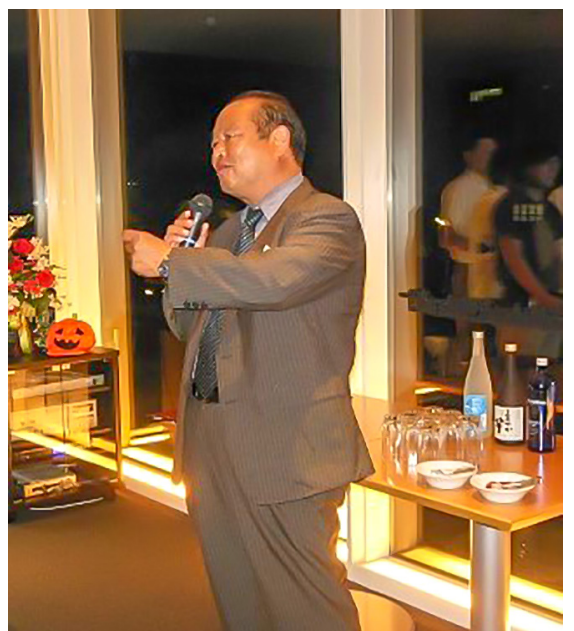

Fig. 1 記念すべき第 1 回講演・見学会の様子. (a) 参加者一同で記念 に一枚. (b) 意見交換会では上田隆宣会長（当時）にご挨拶を 頂戴しました。 
Table I これまでの講演・見学会

\begin{tabular}{|c|c|c|c|c|}
\hline & 開催日 & 開催場所 & 講師 & 講演題目 \\
\hline 第 1 回 & 2013 年 9 月 24 日（火） & 山形大学 & 古川英光 先生 & $\begin{array}{l}\text { 走査型顕微光散乱（SMILS） を活用したソフトマ } \\
\text { ターのイノベーション }\end{array}$ \\
\hline \multirow[b]{2}{*}{ 第 2 回 } & 2013 年 12 月 13 日（金） & 三井化学株式会社 & 伊崎健晴 先生 & 直鎖・分岐高分子のレオロジー特性と構成方程式 \\
\hline & 2013 年 12 月 14 日（土） & 東京理科大学 & 川口靖夫 先生 & $\begin{array}{l}\text { 添加剂による乱流摩擦抵抗の低減一微細な入力で大 } \\
\text { きな省エネを目指す一 }\end{array}$ \\
\hline 第 3 回 & 2014 月 5 月 17 日 (土） & 東京大学 & 大島まり 先生 & 血球と周囲流れの相互作用の観点や液滴について \\
\hline 第 4 回 & 2014 年 10 月 14 日（火） & 福井大学 & 太田貴士 先生 & ニュートン粘性流体乱流の数值シミュレーション \\
\hline 第 5 回 & 2015 年 5 月 12 日（火） & 京都工芸繊維大学 & 萩原良道 先生 & $\begin{array}{l}\text { 高分子（ポリエチレンオキサイド，カラギーナンお } \\
\text { よび不凍タンパク質) 希薄水溶液流に関する私の悪 } \\
\text { 戦苦闘 }\end{array}$ \\
\hline 第 6 回 & 2015 年 9 月 25 日 (金) & 神戸大学 & 鈴木洋 先生 & $\begin{array}{l}\text { 熱輸送スラリーによる高密度熱搬送システムと流動 } \\
\text { 抵抗低減モデル }\end{array}$ \\
\hline 第 7 回 & 2015 年 11 月 6 日 (金) & キリン株式会社 & 辻俊一 先生 & $\begin{array}{l}\text { 希薄溶液としてのビールや飲料中における課題のご } \\
\text { 紹介 }\end{array}$ \\
\hline 第 8 回 & 2016 年 5 月 11 日（水） & 首都大学東京 & 小方聡 先生 & $\begin{array}{l}\text { 親水性・疎水性壁面や天然繊維を利用した流れの抵 } \\
\text { 抗低減 }\end{array}$ \\
\hline \multirow{3}{*}{ 第 9 回 } & \multirow{3}{*}{2016 年 11 月 11 日（金） } & \multirow{3}{*}{ 山口大学 } & 前田修一 先生 & $\begin{array}{l}\text { 企業における物性研究をべースとした新規高分子材 } \\
\text { 料開発 }\end{array}$ \\
\hline & & & 佐伯隆 先生 & $\begin{array}{l}\text { どろどろ・さらさらを科学する一共同研究を通した } \\
\text { 諸活動 }\end{array}$ \\
\hline & & & 貝出絢 先生 & $\begin{array}{l}\text { レオロジーとモルフォロジーによる添加剤の分子設 } \\
\text { 計 }\end{array}$ \\
\hline \multirow{2}{*}{ 第 10 回 } & \multirow{2}{*}{2017 年 5 月 17 日（水） } & \multirow{2}{*}{ 京都大学 } & 巽和也 先生 & マイクロ流路における熱物質輸送と粘弾性流体流れ \\
\hline & & & 栗山怜子 先生 & マイクロスケール熱流動場の光学センシング技術 \\
\hline 第 11 回 & 2017 年 10 月 16 日（月） & 長岡技術科学大学 & 高橋勉 先生 & $\begin{array}{l}\text { 流れにより誘起される構造変化現象を解明するため } \\
\text { の実験手法の開発 }\end{array}$ \\
\hline \multirow{2}{*}{ 第 12 回 } & \multirow{2}{*}{2018 年 5 月 16 日（水） } & \multirow{2}{*}{ 東京農工大学 } & 長津雄一郎 先生 & $\begin{array}{l}\text { 反応界面レオロジーを基軸とするゲル生成反応流研 } \\
\text { 究の展開 }\end{array}$ \\
\hline & & & 田川義之 先生 & $\begin{array}{l}\text { 高粘度液滴 · 流体の高速吐出技術の開発〜界面高速 } \\
\text { 大変形を伴う流れ〜 }\end{array}$ \\
\hline 第 13 回 & 2018 年 10 月 16 日（火） & 九州工業大学 & 中戸晃之 先生 & 無機ナノシート液晶における外場による粒子操作 \\
\hline
\end{tabular}

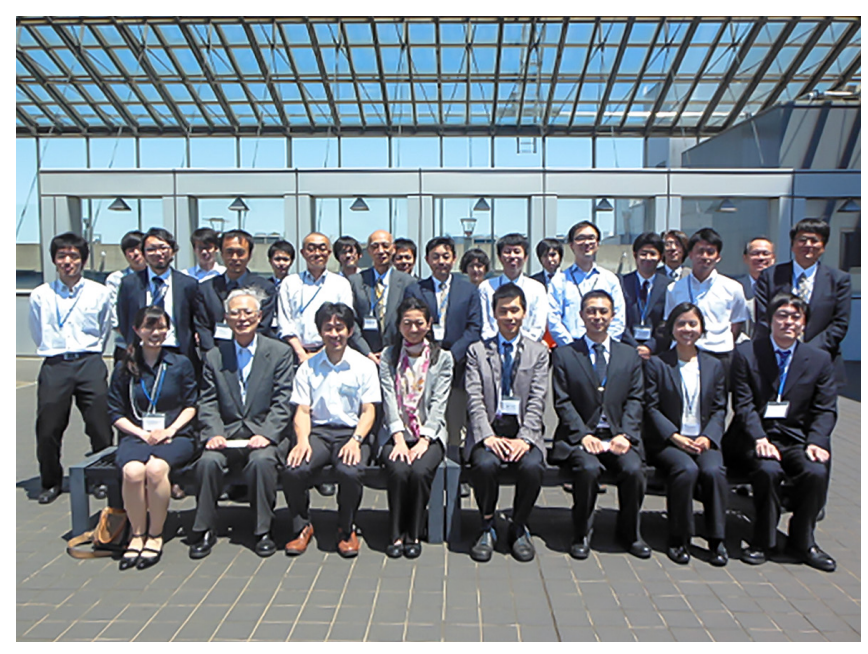

Fig. 2 第 3 回講演・見学会の集合写真. 現在の幹事 5 名が参加してい ます。

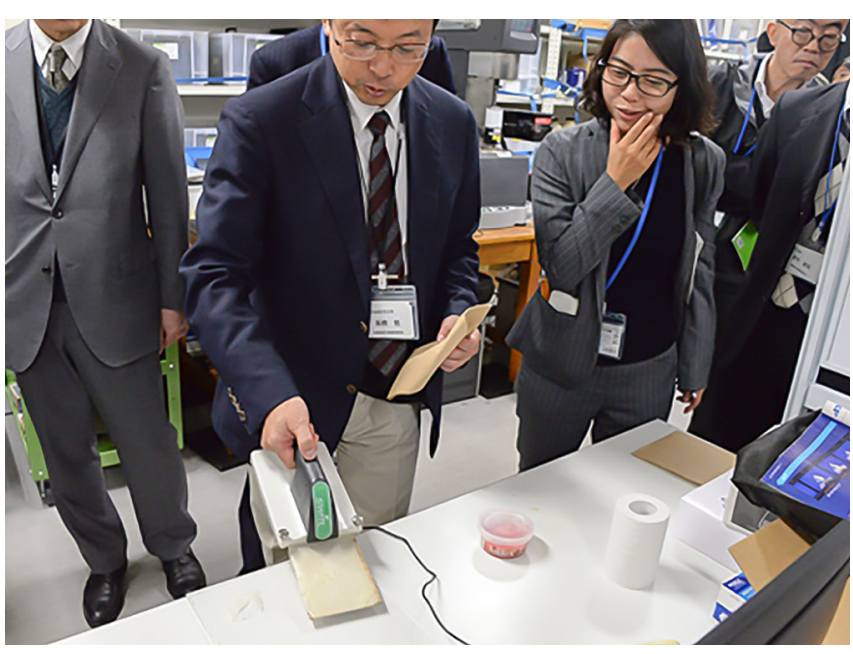

Fig. 3 第 11 回講演・見学会の様子. 何でもきれいに移動できる 「SWITL (スイットル)」の実演および参加者感動中の様子 
催（Fig. 1）して以来, 現在までに13 回の講演・見学会を開 催しています (Fig. 2). いずれの講演・見学会においても実 験装置や実験手法を見学しながら，時には実演を踏まえて (Fig. 3), 活発な情報交換が行われており, 見学型の研究会 の特徵が十分に反映されているものと自負しています。見学 の後の懇親会では参加者が互いに打ち解け, 研究の苦労話や

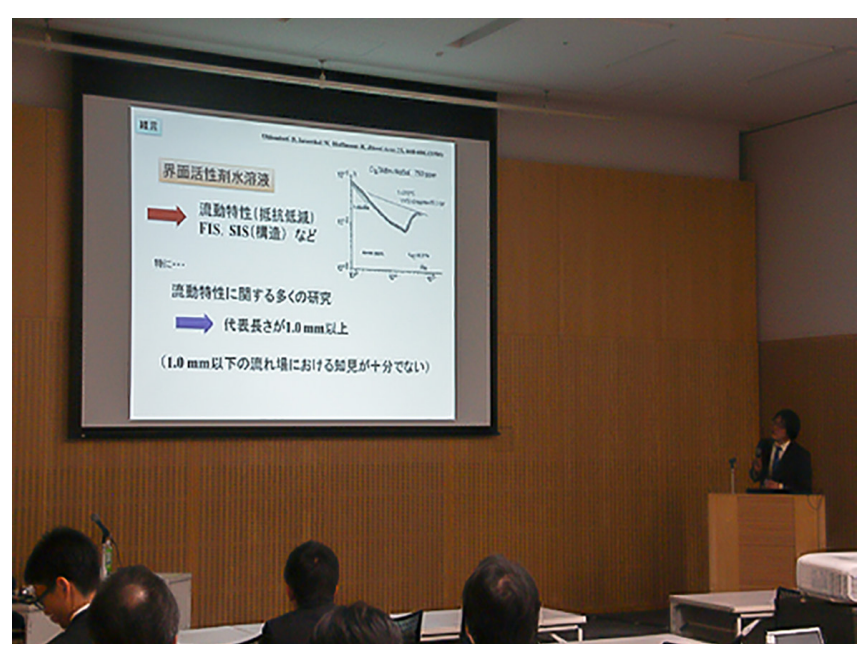

Fig. 4 第 65 回レオロジー討論会における特別セッション「希薄溶液 のレオロジー」の様子.
秘密のノウハウ等, カジュアルながら濃密な会話が飛び交っ ております。

講演・見学会以外の活動として, 日本レオロジー学会誌に おける特集号「希薄溶液の流動学特集号」(Vol. 44, No. 3, 2016）を企画しました。また，第 65 回レオロジー討論会に おいて, 特別セッション「希薄溶液のレオロジー」を企画し ました。普段の講演・見学会とは異なり，希薄溶液に関する 研究発表および濃密な討論が行われました（Fig. 4).

\section{4. おわりに}

以上，簡単ではありますが，研究会のこれまでの活動を紹 介しました，研究会開催は学会を通じて会員の皆様にも案内 しています。また, 研究会ホームページ (http://fluidlab.eng. niigata-u.ac.jp/kihaku_kenkyuukai_index.html）でも，これまで の研究会の様子や開催案内を掲載しています。講演会・見学 会には大学教員だけでなく, 企業の研究者や学生の方にも多 数参加頂いています。百聞は一見に如かず，研究室を見学さ せて頂くのは非常に興味深く，毎回ワクワクした気持ちにな れます。興味を持たれた方は春秋の学会の折，当研究会にも 足を運んでいただけると幸いです。最後に，研究会立ち上げ を後押しして下さった上田隆宣先生, 講演・見学会を快く受 け入れて下さった先生方に改めて深く感謝を申し上げます. 